\title{
SPARKOL LEARNING MEDIA: IS IT EFFECTIVE TO IMPROVE
} STUDENTS' MATHEMATICAL UNDERSTANDING?

\author{
Meri Yani ${ }^{*}$, Sulthan Syahril ${ }^{2}$, Rizki Wahyu Yunian Putra ${ }^{3}$, Adolf T Simatupang ${ }^{4}$ \\ ${ }^{1,2,3}$ Department of Mathematics Education, Universitas Islam Negeri Raden Intan Lampung, Indonesia \\ ${ }^{4}$ Politeknik Bandung, Indonesia
}

*Corresponding author: meriyani060197@gmail.com

\begin{tabular}{l}
\hline \hline Article Info \\
\hline Article history: \\
Received: October 25, 2020 \\
Accepted: November 28, \\
2020 \\
Published: November 30, \\
2020
\end{tabular}

Keywords:

Learning media

Mathematical understanding

Sparkol videoscribe

\begin{abstract}
The aims of this study are to find out the view of the validator on learning Sparkol media, to find out the students' views on learning the Sparkol media, to know the effectiveness of learning by using Sparkol learning media. This research and development used the ADDIE research model. Media development based on Sparkol Videoscribe using Research and Development with Addie model which has 5 stages: Analysis, Design, Development, Implementation, and Evaluation. Student responses to the feasibility of learning media with Sparkol show that this media is feasible and attractive to students. The effectiveness of learning using Sparkol Videoscribe-based mathematics learning media was tested in the range $0,2<E_{s} \leq 0,80$, this result shows that the category is quite effective.
\end{abstract}

\section{MEDIA PEMBELAJARAN SPARKOL: APAKAH EFEKTIF UNTUK MENINGKATKAN PEMAHAMAN MATEMATIS SISWA? \\ Kata Kunci: \\ Media pembelajaran \\ Pemahaman matematis \\ Sparkol videoscribe

\begin{abstract}
ABSTRAK
Tujuan penelitian ini adalah untuk mengetahui pandangan validator tentang media pembelajaran dengan media sparkol, untuk mengetahui pandangan siswa tentang media pembelajaran sparkol, dan untuk mengetahui keefektifan belajar dengan menggunakan media pembelajaransparkol. Penelitian dan pengembangan ini menggunakan model penelitian ADDIE. Respon peserta didik menunjukkan bahwa media ini layak digunakan dan menarik bagi siswa. Keefektifan pembelajaran di MTs Muhammadiyah Bandar Lampung dengan menggunakan media pembelajaran matematika berbasis Sparkol Videoscribe berada pada rentang $0,2<\mathrm{E}_{\mathrm{s}} \leq 0,80$, hasil ini menunjukkan kategori cukup efektif.
\end{abstract}

(C) 2020 Unit Riset dan Publikasi Ilmiah FTK UIN Raden Intan Lampung

\section{INTRODUCTION}

Technology-based learning is very important these days, especially because it can be a special attraction for students [1]. That's why teachers must be familiar with it because teachers are one of the cogs to create potential and quality human characters [2], [3]. The high quality of students will be an example of the successful implementation of formal education in a country.

As one of the sciences that plays a major role in technological advancement, mathematics is considered very important to be studied at all levels of education. However, many students still see mathematics as a scary and difficult subject [4]-[6]. 
When learning mathematics, students tend to memorize rather than understand [7] so that whenever given a different math problem, the results of the students' answers are classified as low [8], [9]. This indicates the need for innovation in learning, one of the learning innovations that according to various studies is effective by utilizing computer technology to increase student understanding [10], [11].

The very rapid development of science and technology, especially in the field of electronics such as computer, laptop, and communication equipment such as various types of smartphones which are supported by various features and applications can be a support for new innovation of learning media [12].

Inevitably, many studies prove that learning using ICT has a positive effect [13] [15]. AECT (Association of Education and Communication Technology) defines the media as all forms and channels used to convey messages or information [1], [16]. Learning media is said to be anything that can be used to convey information or messages during learning process so that it can attract students' attention and interest [17], [18].

It is clear that education must keep up with global developments by utilizing computer software in learning. Mastery of this technology can make it easier for teachers to make various interactive learning media with multimedia concepts [19], [20]. The use of media in learning is expected to make it easier for students to find information precisely and quickly [21], [22].

Sparkol Videoscribe media can combine and synergize media consisting of text, graphics, photos, sound, and music that can be programmed based on learning theory [23] Some of the benefits of using Sparkol Videoscribe are: 1) Sparkol Videoscribe can be used for online business interests such as marketing ideas. 2) Sparkol Videoscribe can be used by educators, such as teachers and lecturers, to deliver material creatively. 3) Sparkol Videoscribe can be used for presentations for educational purposes[24]. The research conducted by Fitri Nurrohmah showed that mathematics learning media with sparkol has a very suitable product quality, with very attractive criteria in large class tests [25].

Based on the above reasons, the authors developed a learning media product with the aim of: 1) To find out the validator's view of the Sparkol Videoscribe mathematics learning media on the concept of two dimentional figures, 2) To find out the students' views on learning media for mathematics, Sparkol Videoscribe to the concept of two dimentional figures. 3) To determine the effectiveness of learning using Sparkol Videoscribe learning media on the concept of two dimentional figures. It is hoped that the development of this media can be a solution to improve students' mathematical understanding, as has been mentioned in previous studies [26].

\section{METHOD}

The type of research used is Research and Development. The product produced from this study is a learning media based on Sparkol Videoscribe on the concept of two dimensional figures for VIII grade students of SMP/MTs (Junior High school). The preliminary study stage of this research and development is the observation carried out at MTs Muhammadiyah Bandar Lampung and the distribution of questionnaires to students and educators at the school. The product trial stage was carried out in class VIII MTs Muhammadiyah Bandar Lampung.

There are five stages in this model, namely Analysis, Design, Development, Implementation, and Evaluation. This research used data collection techniques in the form of interviews, questionnaires, and tests. This research used descriptive qualitative data analysis techniques and quantitative descriptive.

330 Indonesian Journal of Science and Mathematics Education ( I J S M E) 


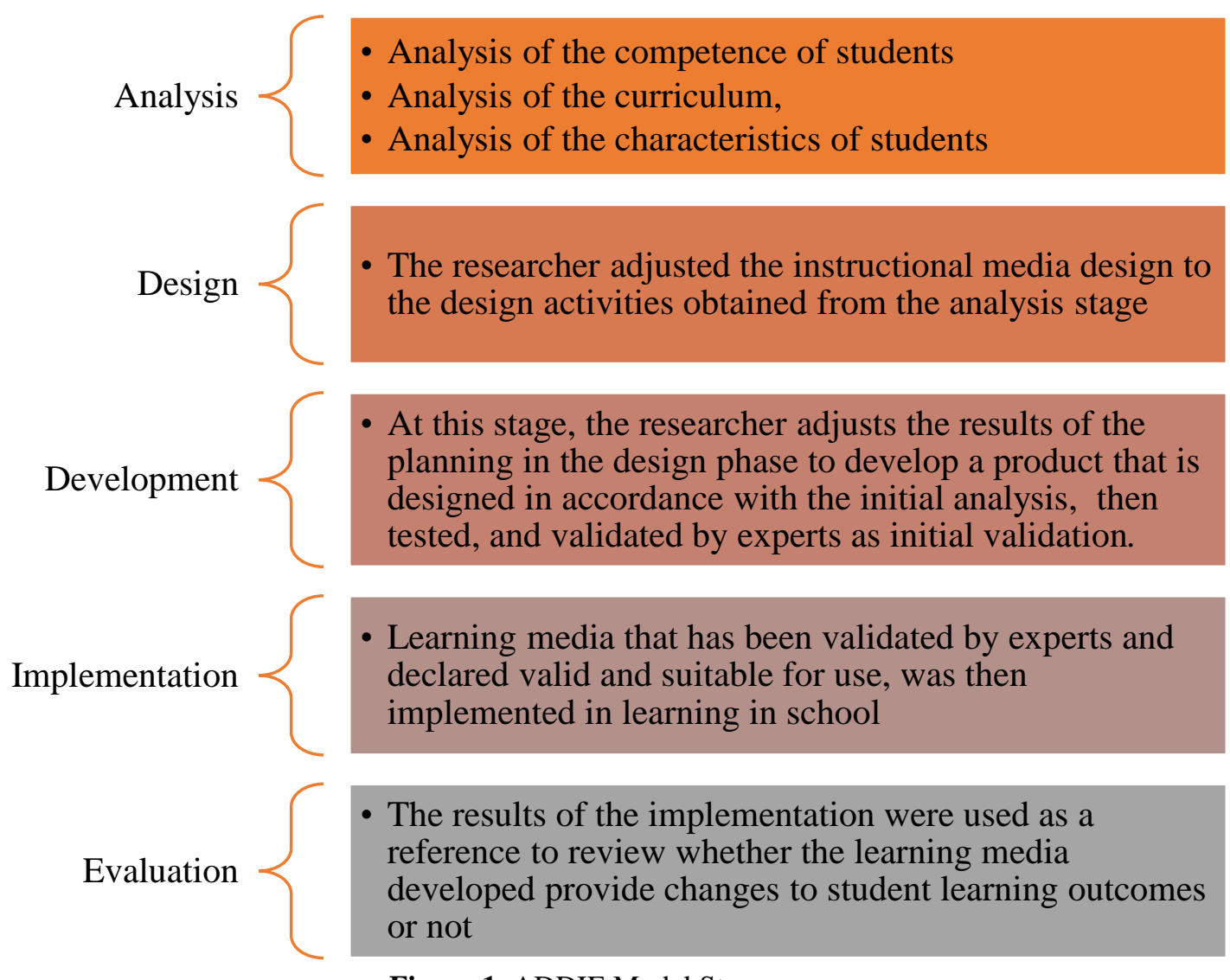

Figure 1. ADDIE Model Stages

\section{RESULTS AND DISCUSSION}

The implementation stage was by applying Prototype 3, Sparkol Videoscribe mathematics learning media, to learning the concept of two-dimensional figures. Based on the results of discussions with mathematics subject teachers at SMP N 19 Bandar Lampung, the classes that will be used as research samples are class VIII B and class VIII $\mathrm{C}$, where class VIII B is used as the respondent for the instrument validation test as well as the limited class test. And class VIII $\mathrm{C}$ is used as a class to test the effectiveness of learning with mathematics learning media Sparkol Videoscribe to the concept of twodimensional figures. Students were given a questionnaire to measure readability and responses to the Sparkol Videoscribe mathematics learning media on the concept of two dimensional figures.

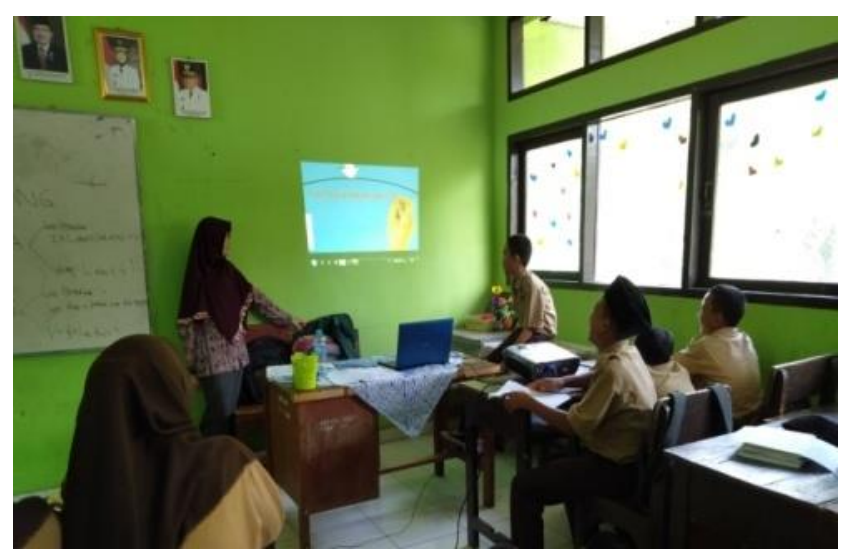

Figure 2. Learning Process 
Based on the results of small-scale tests on 10 students who have high, medium, and low cognitive abilities, it is concluded that the Sparkol Videoscribe mathematics learning media on the two-dimensional figures concept was feasible (Prototype 2) with an average final score of 3.48 .

Then the researchers conducted a small-scale test on ten students in class VIII.U1 MTs Muhammadiyah Bandar Lampung.

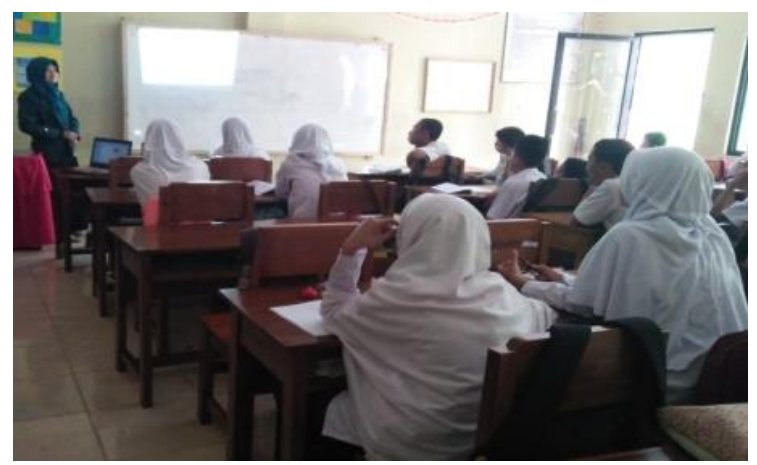

Figure 3. Small-scale Test

The large-scale test is focused on testing the attractiveness of the Sparkol Videoscribe learning media in two-dimensional figures. Students are given a questionnaire to measure readability and responses to learning media. The results of small-scale and large-scale tests related to the learning media are presented in Figure 4.

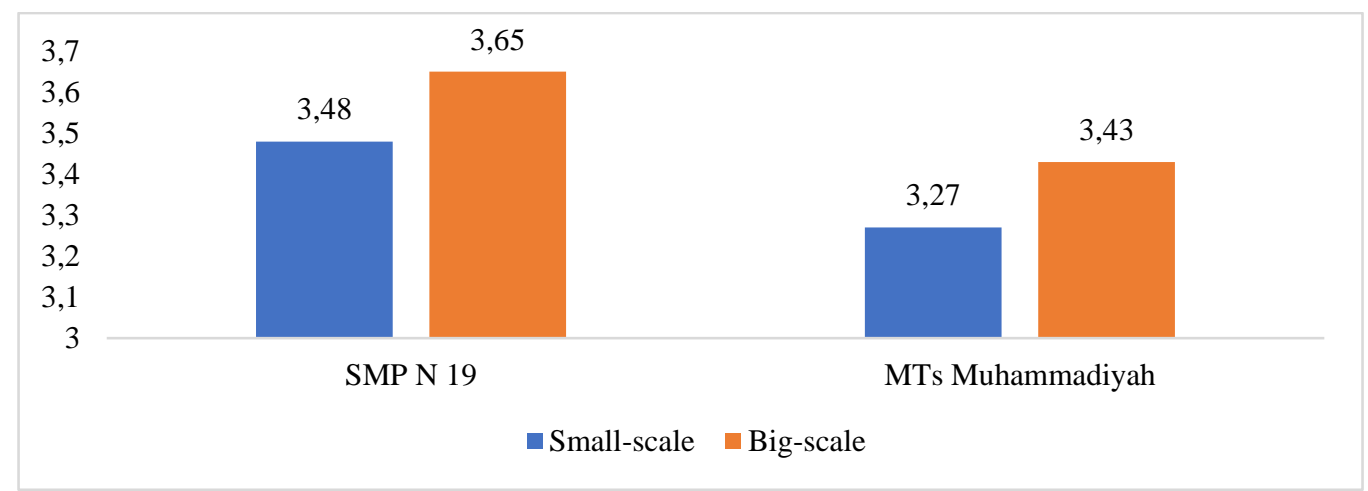

Figure 4. Graph of Small Scale and Large Scale Trial Results

The evaluation stage in this research can be applied at every ADDIE stage. Evaluation is carried out to analyze the data obtained from the research results, namely the analysis of student needs, the preparation of designs, the validity of products from experts, and the results of student response questionnaires. The final results of the evaluation stage show that the products developed in the form of learning media for mathematics, Sparkol Videoscribe on the concept of two-dimensional figures, has a very interesting criteria..

Based on the results of students' answers, the results of the recapitulation of the pretest and posttest scores are presented in Table 1.

Table 1. The Results of Pretest and Posttest

\begin{tabular}{cccccc}
\hline Score & N & Ideal Score & Minimum Score & Maximum Score & Average \\
\hline Pretest & 40 & 100 & 30 & 62 & 43,42 \\
Posttest & 40 & 100 & 47 & 90 & 70,45 \\
\hline
\end{tabular}


Based on the results of the pretest and posttest, then an analysis is carried out to determine the effectiveness of learning using learning media through the Effect Size test.

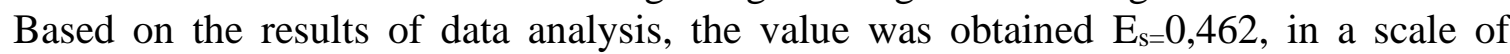
$0,2<\mathrm{E}_{\mathrm{s}} \leq 0,80$, based on the specified category, the level of effectiveness $E_{S}$ learning using mathematics learning media Sparkol Videoscribe is categorized as quite effective.

Mathematics learning media Sparkol Videoscribe in the concept of two-dimensional figures is a solution to develop students' abilities in understanding mathematics. Improving the quality of learning can be done from various aspects of learning variables. The learning variable that is directly related to the quality of learning is the availability of learning media such as quality pictures and videos.

According to several theories, learning using learning media has several advantages so that it can make learning effective for students. One of the advantages of learning media is that it can manage an effective relationship between the two main parties (teachers and students) in the learning process. In addition, learning media can make students' independent learning activities more effective.

The results of this development resulted in a product, namely Sparkol Videoscribe learning media on the concept of two-dimensional figures which has the following characteristics: 1) Basic competency-based learning media in accordance with the 2013 curriculum in accordance with Permendikbud (regulation of the minister of education and culture) no 24 2016. b) The questions are adjusted to the condition of the students' abilities from low questions to difficult questions. c) Designed in an attractive, dynamic, and giving the impression that the competencies being learned can be mastered easily, simply, and meaningfully.

The effectiveness of learning media is measured by the effect size test of the pretest and posttest results of student learning outcomes. The written test is taken after learning activities using Sparkol Videoscribe learning media. The effectiveness of a learning is achieved when the learning material can be absorbed perfectly by students. According to Mulyasa, "effectiveness is related to fulfilling all the main tasks, achieving goals, punctuality and active participation of its members"[27]. Based on the results of the effect size test, it can be concluded that in the learning process, there is a good interaction between students and educators, so that learning becomes active and more meaningful.

The effectiveness of learning media at MTs Muhammadiyah Bandar Lampung is shown by the results of $E_{s}=0,462$ in the range of $0,2<E_{s} \leq 0,80$, based on the category determined the level of effectiveness $E_{S}$ categorized as quite effective with the classification classified as moderate.

\section{CONCLUSION}

Based on the results of the study, it can be concluded that the Sparkol Videoscribe mathematics learning media in mathematics subjects with the concept of two-dimensional figures for class VIII SMP/MTs students are declared feasible and effective. As for suggestions for the development of further learning media: Further learning media are expected to be developed in other mathematical concepts. The researcher hopes that further learning media can be developed on different themes to correct deficiencies in learning media to make it more attractive and efficient.

\section{REFERENCES}

[1] A. Muhson, "Pengembangan Media Pembelajaran Berbasis Teknologi Informasi," $J$. Pendidik. Akunt. Indones., Vol. 8, No. 2, 2010. 
[2] H. Widodo, "Potret Pendidikan Di Indonesia Dan Kesiapannya Dalam Menghadapi Masyarakat Ekonomi Asia (Mea)," Cendekia J. Kependidikan Dan Kemasyarakatan, Vol. 13, No. 2, Pp. 293-308, 2016.

[3] A. Sa'bani, "Pengaruh Problem Based Learning Terhadap Kemampuan Pemecahan Masalah Matematika Siswa," Ekuivalen-Pendidik. Mat., Vol. 26, No. 1, 2017.

[4] Z. A. Mz, "Perspektif Gender Dalam Pembelajaran Matematika," Marwah J. Peremp. Agama Dan Jender, Vol. 12, No. 1, Pp. 15-31, 2013.

[5] A. A. Nugroho, R. W. Y. Putra, F. G. Putra, And M. Syazali, "Pengembangan Blog Sebagai Media Pembelajaran Matematika," Al-Jabar J. Pendidik. Mat., Vol. 8, No. 2, Pp. 197-203, 2017.

[6] E. N. Fauziah, M. G. Jatisunda, And N. Kania, "Analisis Kecemasan Matematis Siswa Madrasah Aliyah," In Seminar Nasional Pendidikan, 2019, Pp. 424-429.

[7] I. W. E. Mahendra, "Project Based Learning Bermuatan Etnomatematika Dalam Pembelajar Matematika," Jpi J. Pendidik. Indones., Vol. 6, No. 1, Pp. 106-114, 2017.

[8] B. S. Anggoro, "Pengembangan Modul Matematika Dengan Strategi Problem Solvin Guntuk Mengukur Tingkat Kemampuan Berpikir Kreatif Matematis Siswa," AlJabar J. Pendidik. Mat., Vol. 6, No. 2, Pp. 121-130, 2015.

[9] P. Akbar, A. Hamid, M. Bernard, And A. I. Sugandi, "Analisis Kemampuan Pemecahan Masalah Dan Disposisi Matematik Siswa Kelas Xi Sma Putra Juang Dalam Materi Peluang," J. Cendekia J. Pendidik. Mat., Vol. 2, No. 1, Pp. 144-153, 2018.

[10] M. Y. Rahim, "Pemanfaatan Ict Sebagai Media Pembelajaran Dan Informasi Pada Uin Alauddin Makassar," Sulesana J. Wawasan Keislam., Vol. 6, No. 2, Pp. 127135, 2016.

[11] J. Warsihna, “'Dilema' Pemanfaatan Teknologi Komunikasi Dan Informasi (Ict) Untuk Meningkatkan Mutu Pendidikan,” J. Teknodik, Pp. 060-076, 2019.

[12] N. Wahyuni, "Pengembangan Media Pembelajaran Compact Disc Interactive (Cd-I) Berbasis Video Scribe Menggunakan Model Pembelajaran Advance Organizer Pada Mata Pelajaran Tkb Kelas X Tav Di Smk Negeri 3 Surabaya," J. Pendidik. Tek. Elektro, Vol. 6, No. 2, 2017.

[13] N. Mahnun, "Media Pembelajaran (Kajian Terhadap Langkah-Langkah Pemilihan Media Dan Implementasinya Dalam Pembelajaran)," -Nida, Vol. 37, No. 1, Pp. 27 34, 2012.

[14] L. N. Amali, "Implikasi Teknologi Informasi Dan Komunikasi Terhadap Dunia Pendidikan," Pros. Aptekindo, Vol. 6, No. 1, 2012.

[15] S. Suryadi, "Peranan Perkembangan Teknologi Informasi Dan Komunikasi Dalam Kegiatan Pembelajaran Dan Perkembangan Dunia Pendidikan," J. Inform., Vol. 3, No. 3, Pp. 9-19, 2015.

[16] H. Baharun, "Pengembangan Media Pembelajaran Pai Berbasis Lingkungan Melalui Model Assure," Cendekia J. Kependidikan Dan Kemasyarakatan, Vol. 14, No. 2, Pp. 231-246, 2016.

[17] U. S. Winataputra, R. Delfi, P. Pannen, And D. Mustafa, "Teori Belajar Dan Pembelajaran," 2014.

[18] I. Darimi, "Teknologi Informasi Dan Komunikasi Sebagai Media Pembelajaran Pendidikan Agama Islam Efektif," J. Pendidik. Teknol. Inf., Vol. 1, No. 2, Pp. 111121, 2017.

[19] A. D. C. Merdekawati, S. Saputro, And S. Sugiharto, "Pengembangan One Stop Learning Multimedia Menggunakan Software Adobe Flash Pada Materi Bentuk

334 Indonesian Journal of Science and Mathematics Education 
Molekul Dan Gaya Antar Molekul Kelas Xi Sma," J. Pendidik. Kim., Vol. 3, No. 1, Pp. 95-103, 2014.

[20] A. Suryadi, "Pemanfaatan Ict Dalam Pembelajaran," J. Pendidik. Terbuka Dan Jarak Jauh, Vol. 8, No. 2, Pp. 83-98, 2007.

[21] D. Sugianto, A. G. Abdullah, S. Elvyanti, And Y. Muladi, "Modul Virtual: Multimedia Flipbook Dasar Teknik Digital," Innov. Vocat. Technol. Educ., Vol. 9, No. 2, 2013.

[22] I. Novianto, "Perilaku Penggunaan Internet Di Kalangan Mahasiswa," Surabaya Univ. Airlangga, 2011.

[23] E. D. Pratiwi, "Pengembangan Media Pembelajaran Fisika Berbasis Sparkol Videoscribe Pokok Bahasan Kinematika Gerak Di Perguruan Tinggi," Uin Raden Intan Lampung, 2017.

[24] A. Zahra, A. Asnimar, S. Srirarasati, And L. Yenny, "Pemanfaatan Media Videoscribe-Sparkol Untuk Meningkatkan Budaya Literasi Guru Dan Peserta Didik," In Seminar Nasional Pendidikan Bahasa Indonesia, 2017, Vol. 1.

[25] F. Nurrohmah, "Pengembangan Media Pembelajaran Matematika Berbantuan Sparkol Pada Materi Penugasan (Proglin) Mahasiswa Matematika Uin Raden Intan Lampung," Uin Raden Intan Lampung, 2018.

[26] Merdeka, "Nadiem Makarim Ungkap Enam Kompetensi Yang Sangat Dibutuhkan Masa Depan," Merdeka.Com, 2019. Https://Www.Merdeka.Com/Peristiwa/NadiemMakarim-Ungkap-Enam-Kompetensi-Yang-Sangat-Dibutuhkan-Masa-Depan.Html (Accessed Jan. 10, 2020).

[27] N. Sutriningsih, "Pembelajaran Lingkaran Melalui Strategi Pemecahan Masalah Sistematis,” J. Maj. Kreasi Stkip Mpl, Vol. 15, No. 1, 2015. 